\title{
LncRNA MIR205HG Drives Esophageal Squamous Cell Carcinoma Progression by Regulating miR-2 I4/SOX4 Axis [Corrigendum]
}

Li H, Jia J, Yang L, et al. Onco Targets Ther. 2020;13:13097-13109.

The authors have advised Figures $3 \mathrm{~A}$ and $3 \mathrm{D}$ on page 13102 are incorrect. Due to an error at the time of figure assembly the migration and invasion images for Figure 3A EC109 panel si-MIR205HG\#3 and 3D EC109 panel si-
MIR205HG\#3 were duplicated. The authors did not pick this error up during the proof-reading stage of the publication. The correct Figure 3 is shown below.

The authors apologize for this error and advise that this does not affect the results of the paper.

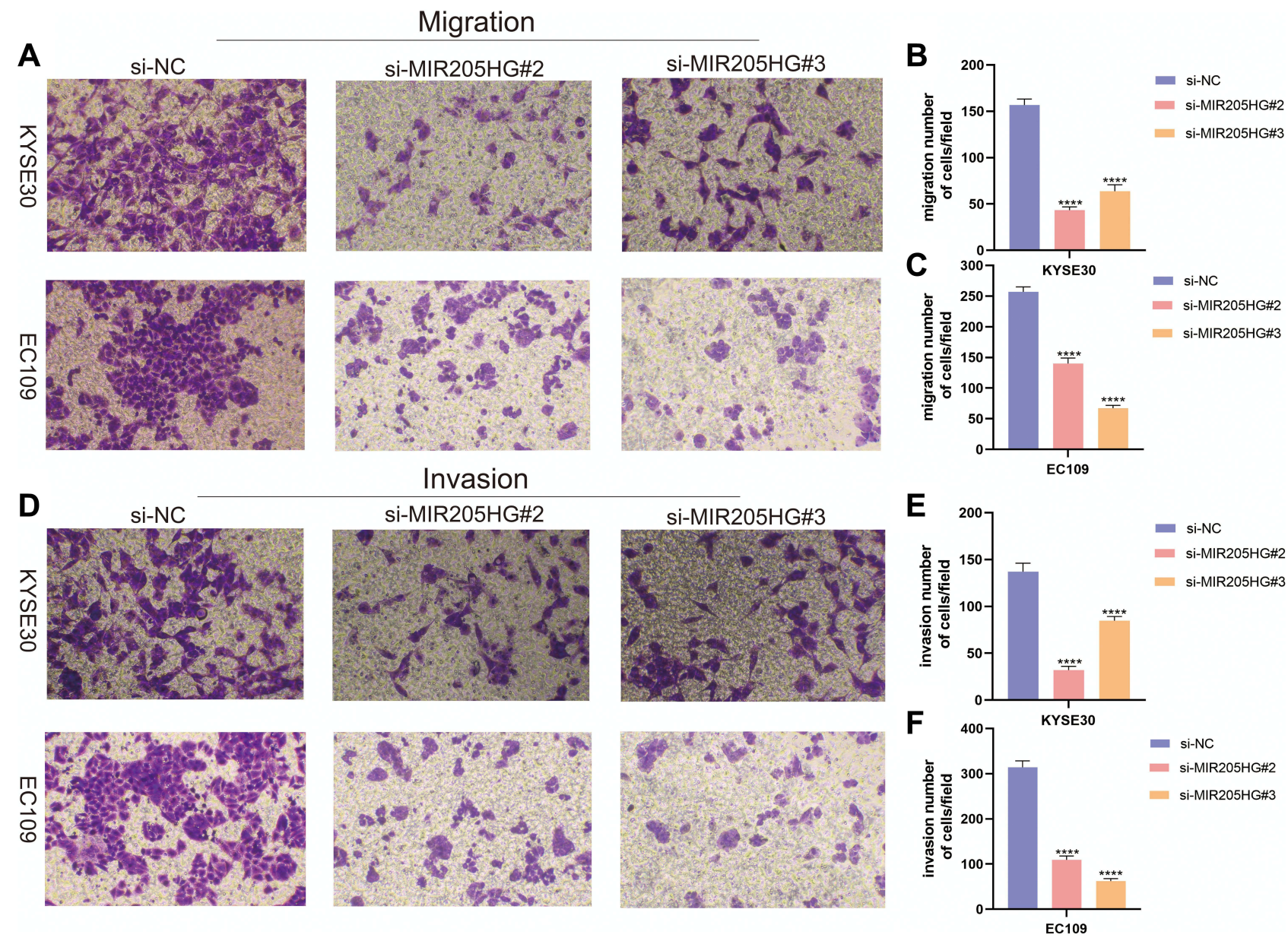

Figure I The authors apologize for this error and advise that this does not affect the results of the paper. 


\section{Publish your work in this journal}

OncoTargets and Therapy is an international, peer-reviewed, open access journal focusing on the pathological basis of all cancers, potential targets for therapy and treatment protocols employed to improve the management of cancer patients. The journal also focuses on the impact of management programs and new therapeutic agents and protocols on patient perspectives such as quality of life, adherence and satisfaction. The manuscript management system is completely online and includes a very quick and fair peer-review system, which is all easy to use. Visit http://www.dovepress.com testimonials.php to read real quotes from published authors.

Submit your manuscript here: https://www.dovepress.com/oncotargets-and-therapy-journal 